University of Nebraska - Lincoln

DigitalCommons@University of Nebraska - Lincoln

Biological Systems Engineering: Papers and

Publications

Biological Systems Engineering

1997

\title{
Films from Laboratory-Extracted Sorghum Kafirin
}

Roberto A. Buffo

University of Nebraska-Lincoln

Curtis L. Weller

University of Nebraska-Lincoln, cweller1@unl.edu

Aristippos Gennadios

University of Nebraska-Lincoln, aris.gennadios@catalent.com

Follow this and additional works at: https://digitalcommons.unl.edu/biosysengfacpub

Part of the Biological Engineering Commons

Buffo, Roberto A.; Weller, Curtis L.; and Gennadios, Aristippos, "Films from Laboratory-Extracted Sorghum Kafirin" (1997). Biological Systems Engineering: Papers and Publications. 105.

https://digitalcommons.unl.edu/biosysengfacpub/105

This Article is brought to you for free and open access by the Biological Systems Engineering at DigitalCommons@University of Nebraska - Lincoln. It has been accepted for inclusion in Biological Systems Engineering: Papers and Publications by an authorized administrator of DigitalCommons@University of Nebraska Lincoln. 


\title{
Films from Laboratory-Extracted Sorghum Kafirin ${ }^{1}$
}

\author{
ROBERTO A. BUFFO,,$^{2,3}$ CURTIS L. WELLER, $, 2,4$ and ARISTIPPOS GENNADIOS ${ }^{5}$
}

Cereal Chem. 74(4):473-475

There has been increased interest in development of biopolymer films and coatings from protein, polysaccharide, and lipid materials in recent years. The qualities of renewability, degradability, compostability, and edibility make such films particularly appealing for food and nonfood packaging applications. Moreover, wide commercialization of biopolymer films will provide a value-added innovative use for traditional agricultural commodities as sources of filmforming materials. Research findings on production, properties, and potential applications of edible films have been reviewed (Krochta 1992, Conca and Yang 1993, Gontard and Guilbert 1994). Protein films in particular have been discussed in detail by Gennadios et al (1994a) and by Torres (1994). Zein, the prolamin fraction of corn proteins, is used in formulations of protective coatings for confectionery items, shelled nuts, and pharmaceutical tablets (Gennadios et al 1994a). Several recent studies have focused on development and property evaluation of zein-based films (Aydt et al 1991; Gennadios et al 1993a,b; Park et al 1994b; Park and Chinnan 1995; Yamada et al 1995), zein-paper laminates (Trezza and Vergano 1994), and methylcellulose and zein-fatty acid laminates (Park et al 1994c, 1996). Functionality of zein in barrier packaging for popcorn (Wu and Schwartzberg 1992), tomatoes (Park et al 1994a), cooked turkey (Herald et al 1996), and shell eggs (Wong et al 1996) has been evaluated.

Kafirin, the prolamin protein fraction of sorghum, is similar to zein in molecular weight, solubility, structure, and amino acid composition (Shull et al 1991). Therefore, kafirin may be considered as a potential alternative for zein in film-forming applications. However, no information has been published related to the film-forming ability of kafirin. Our objective was to evaluate mechanical, water-vapor barrier, and color properties of freestanding films from laboratory-extracted kafirin and compare them to those of zein films.

\section{MATERIALS AND METHODS}

\section{Protein Extraction}

Kafirin was extracted from sorghum gluten with hot ethanol as described by Carter and Reck (1970). The terms sorghum gluten and corn gluten are used here to indicate the protein-rich fractions obtained from wet-milling of sorghum or corn after removal of the fiber-germ and starch fractions. Sorghum gluten was obtained by laboratory wet-milling as described by Buffo (1995). Twenty-four

${ }^{1}$ Journal Series No. 11655, Agricultural Research Division, Institute of Agriculture and Natural Resources, University of Nebraska-Lincoln.

${ }^{2}$ Graduate research assistant and associate professor, respectively, Departments of Biological Systems Engineering, and Food Science \& Technology, University of Nebraska, Lincoln, NE 68583-0726.

${ }^{3}$ Currently graduate research assistant, Department of Food Science and Nutrition, University of Minnesota, St. Paul, MN 55108.

${ }^{4}$ Corresponding author. E-mail: bsen004@unlvm.unl.edu Phone: 402/472-9337. Fax: 402/472-6338

${ }^{5}$ Research scientist, Banner Pharmacaps, Inc., 4125 Premier Drive, High Point, NC 27265 and adjunct assistant professor, Department of Biological Systems Engineering, University of Nebraska, Lincoln, NE 68583-0726.

Publication no. C-1997-0618-03R

(C) 1997 by the American Association of Cereal Chemists, Inc. hybrids (1993 crop year) were wet-milled and their gluten fractions were mixed together into a single kafirin-extractable gluten sample. Before extraction, gluten was defatted by refluxing with hexane in a Soxhlet apparatus for at least $6 \mathrm{hr}$. Defatted gluten and $95 \%$ ethanol $(1: 5, \mathrm{w} / \mathrm{w})$ were placed in a $500-\mathrm{mL}$ flask and vigorously stirred by a water-propulsed stirrer (Kartell, Italy) for $1 \mathrm{hr}$ at $65^{\circ} \mathrm{C}$ within a waterbath (model MW-1120-A1, Blue M Electric Co., Blue Island, IL). The slurry was then vacuum-filtered through a Buchner funnel using qualitative filter paper (Whatman \#2, Whatman Laboratory Division, Maidstone, England), and distilled water was added in excess to the intense orange-colored filtrate to induce kafirin precipitation. The resulting aqueous solution was chilled overnight $\left(\approx-5^{\circ} \mathrm{C}\right)$ to enhance precipitation. Kafirin was recovered by centrifugation (Megafuge 2.0R, Baxter Heraeus Instruments, Germany) at 4,000 $\times g$ for $10 \mathrm{~min}$, washed once with distilled water, centrifuged again to eliminate all ethanol residue and dried for $4-5 \mathrm{hr}$ in an air-convection oven at $50^{\circ} \mathrm{C}$. Reextraction of the retentate on the filter paper did not improve final kafirin yield, so only one extraction was performed per fraction. Before film preparation, dried kafirin was milled in a coffee grinder (model GC-5, Salton Inc., Mt. Prospect, IL).

For yield comparison purposes, samples of corn gluten (unknown origin, donated by D. S. Jackson, Department of Food Science and Technology, University of Nebraska, Lincoln, NE) were extracted in a similar manner to recover zein. However, a commercial zein product (regular grade F4000, Freeman Industries, Tuckahoe, NY), not the laboratory-extracted zein, was used to prepare films for comparisons with kafirin films.

Extraction efficiency was evaluated by two parameters: yield, a percentage value defined as the ratio of dry weight of extracted protein to total solids content $(\mathrm{db})$ of initial gluten $\times 100$; and protein recovery, a percentage value defined as the ratio of dry weight of recovered protein to total dry weight of protein initially present in gluten $\times 100$.

\section{Proximate Analysis and Moisture Content}

Sorghum and corn gluten fractions, extracted kafirin, extracted zein, and commercial zein were analyzed in triplicate for protein content $(\mathrm{N} \times 6.25)$ according to the Corn Refiners Association macro-Kjeldahl method A-18 (CRA 1986) using the Tecator Kjeltec System (Tecator, Hoganas, Sweden). Extracted kafirin and zein were also analyzed in duplicate for crude free fat and ash contents following the AOAC methods 922.05 and 923.03, respectively (AOAC 1984). Starch in extracted kafirin was determined in triplicate according to the rapid enzymatic method 76-12 (AACC 1995). The air oven method 44-15A (AACC 1995) was used to measure moisture content of all materials to obtain proximate compositions on a dry weight basis.

\section{Kafirin Determination}

Kafirin extraction also was evaluated by kafirin recovery, a percentage value defined as the ratio of dry weight of recovered kafirin to total weight of kafirin initially present in gluten $\times 100$. Sorghum gluten was fractionated into prolamins and nonprolamins as described by Wallace et al (1990). Prolamin fractions were 
analyzed in triplicate for protein content $(\mathrm{N} \times 6.25)$ by the microKjeldahl method 46-13 (AACC 1995). SDS-PAGE showed that extracted kafirin was primarily of the $\alpha$-fraction and essentially free of any nonprolamin protein impurities (Buffo 1995). Both kafirin determination and SDS-PAGE of extracted kafirin were performed by B. R. Hamaker, Cereal Laboratory, Department of Food Science, Purdue University, West Lafayette, IN.

\section{Film Preparation}

The formulation $(\mathrm{db})$ reported by Park et al (1994c) was used to prepare kafirin $(89.04 \%$ protein, $6.74 \%$ crude free fat, and $0.04 \%$ ash) and zein (94.82\% protein, $1.82 \%$ crude free fat, and $0.34 \%$ ash) film-forming solutions ( $25 \mathrm{~g}$ of protein, $105.5 \mathrm{~mL}$ of $95 \%$ ethanol, $6.08 \mathrm{~g}$ of glycerin and $5.48 \mathrm{~g}$ of polyethylene glycol 400). Both glycerin and polyethylene glycol, obtained from Fisher Scientific (Pittsburgh, PA), were added as plasticizers to overcome brittleness and to obtain free-standing films. Zein filmforming solutions were stirred while heating to $\approx 85^{\circ} \mathrm{C}$. Kafirin film-forming solutions required more vigorous stirring and had to be heated to boiling to achieve satisfactory kafirin solubilization. Zein's solubilization at a lower temperature and with less vigorous stirring than for kafirin was attributed to textural and density differences. Extracted kafirin was a dense, packed material that clearly contrasted with the light, fluffy texture of commercial zein. Films were carefully peeled from plates and conditioned in the environmental chamber $\left(50 \% \mathrm{rh}\right.$ and $\left.25^{\circ} \mathrm{C}\right)$ for an additional $48 \mathrm{hr}$ before property testing. Film thickness, measured with a handheld micrometer (B.C. Ames Co., Walthan, MA), was $85 \pm 13 \mu \mathrm{m}$ and $81 \pm 12 \mu \mathrm{m}$ for dried kafirin and zein films, respectively.

\section{Film Tensile Testing}

Tensile strength (TS) and percentage elongation at break (E) were both measured with a Universal Testing Machine (model 5566, Instron Corp., Canton, MA) according to ASTM standard method D 882-88 (ASTM 1989) with a slight deviation in that tensile testing of film samples was conducted as quickly as possible in ambient conditions. Five thickness measurements were taken along each specimen with a micrometer and mean thickness was used for TS calculation. TS and E were determined in quintuplicate for each type of film with individually prepared films considered as the replicated experimental units. Each TS and E replicate was the mean of two tested sampling units from the same film.

\section{Film Water Vapor Permeability}

Film water vapor permeability (WVP) was determined at $25^{\circ} \mathrm{C}$ and $50 \%$ rh $(100 / 50 \%)$ gradient as described by Gennadios et al (1994b). Data were corrected to account for resistance of the stagnant air layer $(1 \mathrm{~cm})$ between the film undersides and the surface of water in cups (Gennadios et al 1994c).

\section{Film Color Measurement}

Color values of kafirin and zein films were measured (CR-300 Chromameter, Minolta Camera Co., Osaka, Japan). Film specimens were placed on a white standard plate (calibration plate CR-A43) and the HunterLab color scale was used to measure color: $L=0$ (black) to $L=100$ (white); $-a$ (greenness) to $+a$ (redness); and $-b$ (blueness) to $+b$ (yellowness) (Francis and Clydesdale 1975).

\section{TABLE I}

Mean, Standard Deviation (SD), and Coefficient of Variation (CV) Values for Yield and Recovery of Kafirin and Zein from Ethanol Extraction of Sorghum and Corn Gluten

\begin{tabular}{lrrrc}
\hline & Mean & SD & CV & Replicates \\
\hline Kafirin & & & & \\
$\quad$ Yield & 5.50 & 0.58 & 10.54 & 9 \\
Recovery & 10.71 & 1.07 & 9.99 & 9 \\
Zein & & & & \\
$\quad$ Yield & 16.34 & 3.30 & 20.20 & 4 \\
Recovery & 35.47 & 7.16 & 20.19 & 4 \\
\hline
\end{tabular}

Standard values for the white plate were $L=96.86, a=-0.02$ and $b=1.99$. Ten measurements were taken per each type of film.

\section{Statistical Analysis}

Statistical Analysis System software was used to analyze experimental data (SAS Institute, Cary, NC). Means, standard deviations, coefficients of variation, and $F$-tests were obtained through the SAS general linear models procedure.

\section{RESULTS AND DISCUSSION}

\section{Extraction Evaluation}

Kafirin and zein were obtained from sorghum and corn gluten, respectively, applying similar extraction procedures. Although a more aqueous alcohol (70\% rather than the $95 \%$ used) could have improved extraction yields according to solubility characteristics of prolamins, it was observed that even a slightly more aqueous environment induced gelatinization of starch contained in gluten. Therefore, a nearly anhydrous ethanol (95\%) had to be used to achieve a satisfactory extraction of zein and kafirin, even though some yield was being sacrificed. Yield and protein recovery values are given in Table I. Computations were based on initial protein contents of $51.82 \% \mathrm{db}$ for sorghum gluten and $48.10 \% \mathrm{db}$ for corn gluten.

Both yield and protein recovery were around three times greater for zein than for kafirin, indicating that zein was easier to extract under these specific conditions. Furthermore, based on the determined initial kafirin content of sorghum gluten, a kafirin recovery of only $9.57 \pm 0.97 \%$ (coefficient of variation $10.13 \%$; nine replicates) was obtained. Hamaker et al (1994) reported that kafirin completely solubilized in aqueous alcohol when a reducing agent was added to break the numerous disulfide linkages the prolamin forms within protein bodies in the kernel. Most likely, absence of a reducing agent to disrupt disulfide bonds considerably lowered kafirin yield and recovery values. For chemical studies, kafirin is currently extracted with mercaptoethanol, a strong reducing agent (Hamaker et al 1995). Mercaptoethanol was not used in this study to maintain protein edibility. Kafirin extractability may be enhanced with addition of FDA-approved reducing agents such as sulfites to the alcoholic extracting solution.

\section{Film Properties}

Kafirin films had lower TS $(P<0.05)$ and higher E $(P<0.01)$ than zein films (Table II). This may be attributed to extracted kafirin material having lower protein content than the commercial zein product because nonprotein constituents are likely to disrupt homogeneity and continuity of protein film networks. In agreement with this, Wall and Beckwith (1969) reported that cast films from commercial wheat gluten had lower TS and higher E than cast films from laboratory-prepared wheat gluten of higher purity. Also, films prepared from a $75 \%$ protein content commercial wheat gluten had lower TS than films prepared from an $82 \%$ protein

TABLE II

Mean \pm Standard Deviation Values for Tensile Strength, Elongation at Break, Water Vapor Permeability, and HunterLab Color Values of Kafirin and Zein Films ${ }^{a}$

\begin{tabular}{|c|c|c|}
\hline & Kafirin Films & Zein Films \\
\hline Tensile strength (MPa) & $2.1 \pm 0.3$ & $2.6 \pm 0.3$ \\
\hline Elongation at break $(\%)$ & $106.1 \pm 9.7$ & $84.4 \pm 3.5$ \\
\hline Water vapor permeability & $5.5 \pm 0.2$ & $5.7 \pm 0.3$ \\
\hline \multicolumn{3}{|l|}{ HunterLab color values ${ }^{\mathrm{c}}$} \\
\hline$L$ & $75.48 \pm 2.85$ & $94.03 \pm 0.53$ \\
\hline$a$ & $7.27 \pm 1.85$ & $-5.44 \pm 0.47$ \\
\hline$b$ & $48.10 \pm 4.70$ & $29.42 \pm 4.74$ \\
\hline
\end{tabular}

${ }^{a}$ For all properties except water vapor permeability, means were significantly $(P<0.05)$ different between kafirin and zein films.

${ }^{\mathrm{b}} \mathrm{g} \cdot \mathrm{mm} / \mathrm{m}^{2} \cdot \mathrm{hr} \cdot \mathrm{kPa}$.

${ }^{c} L=0$ (black) to $L=100$ (white); $-a$ (greenness) to $+a$ (redness); and $-b$ (blueness) to $+b$ (yellowness) 
content commercial wheat gluten (Gennadios and Weller 1992). According to Evans et al (1987), kafirin has a total hydrophobic amino acid (alanine, isoleucine, leucine, methionine, proline, and valine) content of $58.3 \% \mathrm{~mol}$. This is slightly higher than the total hydrophobic amino acid content of $56.2 \%$ mol reported for zein by Wilson (1987). Furthermore, the extracted kafirin material in this study had a higher crude free fat content than the commercial zein product. Therefore, it was expected that kafirin films would have exhibited lower WVP than zein films. However, WVP values of kafirin and zein were not significantly $(P>0.05)$ different (Table II).

Color characteristics of films may become important factors for consumer acceptance in packaging applications. Kafirin films had significantly $(P<0.01)$ lower $L$ (darker), higher $a$ (redder), and lower $b$ (more yellow) values than zein films (Table II). Probably, the more intense color of kafirin films was due to a higher content of inherent pigments in extracted kafirin than in zein. Also, occurrence of the Maillard reaction might have contributed to the coloration of kafirin films. As mentioned, no starch was detected in extracted kafirin. However, it is possible that the alcoholic extract had carried simple sugars (e.g., glucose, fructose, raffinose, and stachyose) readily available to undergo Maillard reaction (Watson 1984).

\section{Implications}

Films from laboratory-extracted sorghum kafirin had tensile and water vapor barrier properties similar to films from commercial corn zein. Color-wise, kafirin films were more intensely colored than zein films. It is anticipated that advancements in the kafirin extraction process will improve the film-forming ability and film properties, including color characteristics, of kafirin. Yields of extracted kafirin could be increased by use of sulfites to break down protein disulfide linkages and by exhaustive removal of oil. Also, extracting solvents other than ethanol may improve the kafirin isolation process. This study indicated that sorghum kafirin has potential to be used as a biopolymer for edible or nonedible film and coating applications.

\section{ACKNOWLEDGMENT}

This work was supported in part by the Nebraska Grain Sorghum Development, Utilization and Marketing Board.

\section{LITERATURE CITED}

American Association of Cereal Chemists. 1995. Approved Methods of the AACC, 9th ed. The Association: St. Paul, MN.

AOAC. 1984. Official Methods of Analysis of the Association of Official Analytical Chemists, 14th ed. The Association: Washington, DC.

ASTM. 1989. Annual Book of American Society for Testing and Materials Standards. Standard methods for tensile properties of thin plastic sheeting D 882-88. Standard test methods for water vapor transmission of materials E 96-80. The Society: Philadelphia, PA.

Aydt, T. P., Weller, C. L., and Testin, R. F. 1991. Mechanical and barrier properties of edible corn and wheat protein films. Trans. ASAE 34:207-211.

Buffo, R. A. 1995. Optimization of sorghum kernel components separation and kafirin utilization. MS thesis. University of Nebraska, Lincoln.

Carter, R., and Reck, D. R. 1970. Low temperature solvent extraction process for producing high purity zein. U.S. patent 3,535,305.

Conca, K. R., and Yang, T. C. S. 1993. Edible food barrier coatings. Pages 357-369 in: Biodegradable Polymers and Packaging. C. C. Ching, D. L. Kaplan, and E. L. Thomas, eds. Technomic Publishing: Lancaster, PA.

CRA. 1986. Standard Analytical Methods of the Member Companies of Corn Industry Research Foundation. Method A-18, approved June 1957. Corn Refiners Assoc.: Washington, DC.

Evans, D. J., Schussler, L., and Taylor, J. R. N. 1987. Isolation of reducedsoluble protein from sorghum starchy endosperm. J. Cereal Sci. 5:61-65.

Francis, F. J., and Clydesdale, F. M. 1975. Food Colorimetry: Theory and Applications. Avi Publishing: Westport, CT.

Gennadios, A., and Weller, C. L. 1992. Tensile strength increase of wheat gluten films. ASAE Paper 92-6517. Am. Soc. .Agric. Eng.: St. Joseph, MI.
Gennadios, A., Park, H. J., and Weller, C. L. 1993a. Relative humidity and temperature effects on tensile strength of edible protein and cellulose ether films. Trans. ASAE 36:1867-1872.

Gennadios, A., Weller, C. L., and Testin, R. F. 1993b. Temperature effect on oxygen permeability of edible protein-based films. J. Food Sci. $58: 212-214,219$

Gennadios, A., McHugh, T. H., Weller, C. L., and Krochta, J. M. 1994a. Edible coatings and films based on proteins. Pages 201-277 in: Edible Coatings and Films to Improve Food Quality. J. M. Krochta, E. A. Baldwin, and M. Nisperos-Carriedo, eds. Technomic Publishing: Lancaster, PA.

Gennadios, A., Ghorpade, V. M., Weller, C. L., and Hanna, M. A. 1994b. Heat curing of soy protein films. Trans. ASAE 39:575-579.

Gennadios, A., Weller, C. L., and Gooding, C. H. 1994c. Measurement errors in water vapor permeability of highly permeable, hydrophilic edible films. J. Food Eng. 21:395-409.

Gontard, N., and Guilbert, S. 1994. Bio-packaging: Technology and properties of edible and/or biodegradable material of agricultural origin. Pages 159-181 in: Food Packaging and Preservation. M. Mathlouthi, ed. Blackie Academic \& Professional: London.

Hamaker, B. R., Mertz, E. T., and Axtell, J. D. 1994. Effect of extrusion on sorghum kafirin solubility. Cereal Chem. 71:515-517.

Hamaker, B. R., Mohamed, A. A., Habben, J. E., Huang, C. P., and Larkins, B. A. 1995. Efficient procedure for extracting maize and sorghum kernel proteins reveals higher prolamin contents than the conventional method. Cereal Chem. 72:583-588.

Herald, T. J., Hachmeister, K. A., Huang, S., and Bowers, J. R. 1996. Corn zein packaging materials for cooked turkey. J. Food Sci. 61:415-417, 421.

Krochta, J. M. 1992. Control of mass transfer in foods with edible coatings and films. Pages 517-538 in: Advances in Food Engineering. R. P. Singh and M. A. Wirakartakasumah, eds. CRC Press: Boca Raton, FL.

Park, H. J., and Chinnan, M. S. 1995. Gas and water vapor barrier properties of edible films from protein and cellulosic materials. J. Food Eng. 25:497-507.

Park, H. J., Chinnan, M. S., and Shewfelt, R. L. 1994a. Edible coating effects on storage life and quality of tomatoes. J. Food Sci. 59:568-570.

Park, H. J., Bunn, J. M., Weller, C. L., Vergano, P. J., and Testin, R. F. 1994b. Water vapor permeability and mechanical properties of grain protein-based films as affected by mixtures of polyethylene glycol and glycerin plasticizers. Trans. ASAE 37:1281-1285.

Park, J. W., Testin, R. F., Park, H. J., Vergano, P. J., and Weller, C. L. 1994c. Fatty acid concentration effect on tensile strength, elongation and water vapor permeability of laminated edible films. J. Food Sci. 59:916-919.

Park, J. W., Testin, R. F., Vergano, P. J., Park, H. J., and Weller, C. L. 1996. Fatty acid distribution and its effect on oxygen permeability in laminated edible films. J. Food Sci. 61:401-406.

Shull, J. M., Watterson, J. J., and Kirleis, A. W. 1991. Proposed nomenclature for the alcohol-soluble proteins (kafirins) of Sorghum bicolor (L. Moench) based on molecular weight, solubility, and structure. J. Agric. Food Chem. 39:83-87.

Torres, J. A. 1994. Edible films and coatings from proteins. Pages 467507 in: Protein Functionality in Food Systems. N. S. Hettiarachchy and G. R. Ziegler, eds. Marcel Dekker: New York.

Trezza, T. A., and Vergano, P. J. 1994. Grease resistance of corn zein coated paper. J. Food Sci. 59:912-915.

Wall, J. S., and Beckwith, A. C. 1969. Relationship between structure and rheological properties of gluten proteins. Cereal Sci. Today 14:16-18, 20-21.

Wallace, J. C., Lopes, M. A., Paiva, E., and Larkins, B. A. 1990. New methods for extraction and quantitation of zein reveal a high content of $\gamma$-zein in modified opaque-2-maize. Plant Physiol. 92:191-196.

Watson, S. A. 1984. Corn and sorghum starches: Production. Pages 417468 in: Starch: Chemistry and Technology, 2nd ed. R. L. Whistler, J. W. BeMiller and E. F. Paschall, eds. Academic Press: Orlando, FL.

Wilson, C. M. 1987. Protein of the kernel. Pages 273-310 in: Corn: Chemistry and Technology. S. A. Watson and P. E. Ramstad, eds. AACC: St. Paul, MN.

Wong, Y. C., Herald, T. J., and Hachmeister, K. A. 1996. Evaluation of mechanical and barrier properties of protein coatings on shell eggs. Poultry Sci. 75:417-422.

Wu, P. J., and Schwartzberg, H. G. 1992. Popping behavior and zein coating of popcorn. Cereal Chem. 69:567-573.

Yamada, K., Takahashi, H., and Nogushi, A. 1995. Improved water resistance in edible zein films and composites for biodegradable food packaging. Int. J. Food Sci. Technol. 30:599-608.

[Received September 12, 1996. Accepted March 31, 1997.] 